\title{
HNPCC: Six new pathogenic mutations
}

Erdmute Kunstmann*1, Judith Vieland ${ }^{1}$, Frank E Brasch ${ }^{3}$, Stephan A Hahn², Joerg T Epplen ${ }^{1}$, Karsten Schulmann² and Wolff Schmiegel ${ }^{2,4}$

\author{
Address: ${ }^{1}$ Human Genetics, University of Bochum, Bochum, Germany, ${ }^{2}$ Medical Department Knappschaftskrankenhaus, University of Bochum, \\ Bochum, Germany, ${ }^{3}$ Institute of Pathology, University Hospital Bergmannsheil, University of Bochum, Bochum, Germany and ${ }^{4}$ Division of \\ Gastroenterology and Hepatology, University Hospital Bergmannsheil, University of Bochum, Bochum, Germany \\ Email: Erdmute Kunstmann* - erdmute.kunstmann@rub.de; Judith Vieland - judith_vieland@ hotmail.com; \\ Frank E Brasch - frank.e.brasch@ruhr-uni-bochum.de; Stephan A Hahn - Stephan.Hahn@ruhr-uni-bochum.de; \\ Joerg T Epplen - Joerg.T.Epplen@ruhr-uni-bochum.de; Karsten Schulmann - karsten.schulmann@ruhr-uni-bochum.de; \\ Wolff Schmiegel - Wolff.Schmiegel@ruhr-uni-bochum.de \\ * Corresponding author
}

Published: 24 June 2004

BMC Medical Genetics 2004, 5:16 doi:10.1 |86/147|-2350-5-16

This article is available from: http://www.biomedcentral.com/I47I-2350/5/16
Received: 05 April 2004

Accepted: 24 June 2004

(C) 2004 Kunstmann et al; licensee BioMed Central Ltd. This is an Open Access article: verbatim copying and redistribution of this article are permitted in all media for any purpose, provided this notice is preserved along with the article's original URL.

\begin{abstract}
Background: Hereditary non-polyposis colorectal cancer (HNPCC) is an autosomal dominant disease with a high risk for colorectal and endometrial cancer caused by germline mutations in DNA mismatch-repair genes (MMR). HNPCC accounts for approximately 2 to $5 \%$ of all colorectal cancers. Here we present 6 novel mutations in the DNA mismatch-repair genes MLHI, MSH2 and MSH6.

Methods: Patients with clinical diagnosis of HNPCC were counselled. Tumor specimen were analysed for microsatellite instability and immunohistochemistry for MLHI, MSH2 and MSH6 protein was performed. If one of these proteins was not detectable in the tumor mutation analysis of the corresponding gene was carried out.

Results: We identified 6 frameshift mutations ( 2 in $M L H I, 3$ in MSH2, I in MSH6) resulting in a premature stop: two mutations in MLHI (c.2198_2199insAACA [p.N733fsX745], c.2076_2077delTG [p.G693fsX702]), three mutations in MSH2 (c.810_8I I delGT [p.C27IfsX282], c.763_766delAGTGinsTT [p.F255fsX282], c.873_876delGACT [p.L292fsX298]) and one mutation in MSH6 (c.142I_I422dupTG [p.C475fsX480]). All six tumors tested for microsatellite instability showed high levels of microsatellite instability (MSI-H).
\end{abstract}

Conclusions: HNPCC in families with MSH6 germline mutations may show an age of onset that is comparable to this of patients with $M L H I$ and $M S H 2$ mutations.

\section{Background}

Hereditary nonpolyposis colorectal cancer (HNPCC) is characterized by very high risk for colorectal cancer [1]. In addition, endometrial and ovary cancer risk as well as risk for tumors of the ureter, renal pelvic and small intestine is increased. Germline mutations of MLH1 and MSH2 account for $70 \%$ of all HNPCC cases [2]. Approximately
$5-10 \%$ of HNPCC families carry a germline mutation in the MSH6 gene [3-5]. Here we report six germline mutations in the mismatch-repair genes MLH1, MSH2 and MSH6, that to our best knowledge have not been described (Medline and HNPCC mutation database http:/ /www.nfdht.nl. 


\section{Methods}

This study was approved by the ethical committee of the Medical Faculty of the Ruhr-University Bochum. All patients underwent interdisciplinary counselling by a geneticist, clinician and psychologist. Patients included in this study fulfilled the Amsterdam or Bethesda criteria [1]. Substantial pedigree information moreover including the revised Bethesda criteria [6] is given in table 1. After given informed consent blood samples were drawn for genetic testing. Genomic DNA was extracted using standard protocol [7].

Formalin fixed and paraffin embedded tumor tissues were obtained from different primary pathologists and sent upon request to the local reference pathology of the Familial Colorectal Cancer Center of the Ruhr University Bochum. Tumors were reexamined for histomorphological HNPCC features, immunohistochemical MMR repair protein expression and microsatellite instability.

\section{Microsatellite Analysis}

Tumor and surrounding normal tissue were microdissected by a skilled pathologist. Tumor cell cellularity was at least 70\%. DNA was isolated with the QIAamp DNA Mini Kit (Qiagen, Hilden, Germany). Microsatellite mark- ers BAT-25, BAT-26, D5S346, D17S250, D2S123 and BAT-40 were amplified. The markers included the NIH reference panel according to the international guidelines for the evaluation of MSI in colorectal cancer (Boland et al., 1998). Primer sequences are available on request. Tumors were classified as having high grade microsatellite instability (MSI-H) if at least $30 \%$ of the markers showed instabilities. Microsatellite-PCR reactions were performed in 96-well microtiter plates, in $20 \mathrm{mmol} / \mathrm{L}$ Tris- $\mathrm{HCl}, \mathrm{pH}$ $8.4,5 \mathrm{mmol} / \mathrm{L} \mathrm{KCl}, 1.5 \mathrm{mmol} / \mathrm{L} \mathrm{MgCl} 2,100 \mathrm{ng}$ of each primer, $200 \mathrm{mmol} / \mathrm{L}$ dNTPs, $60 \mathrm{mmol} / \mathrm{L}$ TMAC (Sigma, Taufkirchen, Germany), 1.5\% formamide, $2 \mathrm{ml}$ DNA template (tumor or normal tissue), and 1.5 units Taq DNA polymerase (Gibco BRL, Karlsruhe, Germany), in a final volume of $15 \mathrm{ml}$. Reactions were performed in a Hybaid Touchdown temperature cycler (MWG-Biotech, Ebersberg, Germany), for 40 cycles of $94^{\circ} \mathrm{C}$ for 15 seconds, different annealing temperatures for each marker for 30 seconds, and $72^{\circ} \mathrm{C}$ for 30 seconds, and a final extension at $72{ }^{\circ} \mathrm{C}$ for 5 minutes. BAT-25, BAT-26, BAT-40 and D2S123 were amplified with an annealing temperature of $60^{\circ} \mathrm{C}$, whereas D5S346 was performed at $58^{\circ} \mathrm{C}$ and D17S250 at $53^{\circ} \mathrm{C}$. PCR products were separated on $6 \%$ polyacrylamide, $8 \mathrm{~mol} / \mathrm{L}$ urea gels and DNA fragments were visualized by silver staining.

Table I: Pedigree information and clinical diagnosis of the investigated patients

\begin{tabular}{|c|c|c|c|}
\hline Patient ID & Clinical diagnosis & Manifestation patient (age of diagnosis) & Manifestation family members (age of diagnosis) \\
\hline $0546-2$ & AMS II & CRC (32) & $\begin{array}{l}\text { Mother: adenocarcinoma in the small pelvis (39) } \\
\text { brother of mother: CRC (35) } \\
\text { sister of mother: endometrial carcinoma (35) } \\
\text { sister of mother. endometrial carcinoma (53), CRC (54) } \\
\text { grandfather: CRC ( } 42) \\
\text { sister of grandfather: CRC (66) } \\
\text { sister of grandfather: CRC (48) } \\
\text { brother of grandfather: gastric cancer (34) }\end{array}$ \\
\hline $0699-3$ & $B 2,3$ and $4 / B_{r} I, 2$, and 4 & CRC $(40 ; 53)$ & $\begin{array}{l}\text { Mother: breast cancer (45) } \\
\text { grandmother: CRC (70) } \\
\text { cousin of mother: endometrial carcinoma (45) } \\
\text { cousin of mother: CRC (40); endometrial carcinoma (48) } \\
\text { daughter of cousin: CRC (33) }\end{array}$ \\
\hline $0545-0$ & $B 2,3$ and $4 / B_{r} I, 2$ and 4 & CRC (29) & Father: CRC $(52 ; 55 ; 58)$ \\
\hline $0729-5$ & AMS I & CRC $(44 ; 46 ; 54)$ & $\begin{array}{l}\text { Father: CRC (55) } \\
\text { Grandfather CRC (unknown age) }\end{array}$ \\
\hline $0660-6$ & AMS I & CRC (42) & $\begin{array}{l}\text { mother: CRC ( } 30 \text { and } 57) \\
\text { grandmother: endometrial carcinoma (47), lung cancer (48) } \\
\text { sister of grandmother: CRC ( } 5 \mathrm{I}) \\
\text { sister of grandmother: endometrial carcinoma (50) } \\
\text { brother of grandmother: CRC (53 and } 65)\end{array}$ \\
\hline $0531-X$ & $\mathrm{~B} 7 / \mathrm{B}_{\mathrm{r}} \mathrm{I}$ & colon adenoma $(39 ; 4 I)$ & $\begin{array}{l}\text { Sister: colon adenoma }(4 I) \\
\text { Grandmother: CRC (40) }\end{array}$ \\
\hline
\end{tabular}

AMS I Amsterdam criteria; AMS II Amsterdam criteria revised; B Bethesda criteria, $B_{r}$ revised Bethesda criteria; CRC colorectal cancer 
Table 2: Microsatellite status and immunohistochemical staining of tumor tissue, result of sequencing analysis in all investigated patients.

\begin{tabular}{|c|c|c|c|c|c|c|}
\hline Patient ID & MS-status & $\begin{array}{l}\text { Immunohistochem } \\
\text { ical staining of } \\
\text { tumor tissue }\end{array}$ & Gene & Exon & Mutation & $\begin{array}{l}\text { Length of } \\
\text { predicted protein } \\
\text { after truncation }\end{array}$ \\
\hline $0546-2$ & MSI-H & $\begin{array}{l}\text { MLHI neg, MSH2 } \\
\text { pos, MSH6 pos }\end{array}$ & MLHI & 19 & $\begin{array}{l}\text { c.2198_2199insAA } \\
\text { CA } \\
\text { [p.N733fs X745] }\end{array}$ & Cd 745 \\
\hline $0699-3$ & MSI-H & $\begin{array}{l}\text { MLHI neg, MSH2 } \\
\text { pos, MSH6 pos }\end{array}$ & MLHI & 18 & $\begin{array}{l}\text { c.2076_2077delT } \\
\text { G [p.G693fsX702] }\end{array}$ & Cd 702 \\
\hline $0545-0$ & MSI-H & $\begin{array}{l}\text { MSH2 neg, MSH6 } \\
\text { neg, MLHI pos }\end{array}$ & $\mathrm{MSH} 2$ & 5 & $\begin{array}{l}\text { c.810_8I IdelGT } \\
{[\text { p.C27IfsX282] }}\end{array}$ & $\mathrm{Cd} 28 \mathrm{I}$ \\
\hline $0729-5$ & MSI-H & $\begin{array}{l}\text { MSH2 red, MSH6 } \\
\text { neg, } M L H I \text { pos }\end{array}$ & $\mathrm{MSH} 2$ & 4 & $\begin{array}{l}\text { c.763_766delAGT } \\
\text { GinsTT } \\
\text { [p.F255fsX282] }\end{array}$ & Cd 282 \\
\hline $0660-6$ & MSI-H & $\begin{array}{l}\text { MSH2 neg, MSH6 } \\
\text { neg, MLHI pos }\end{array}$ & $\mathrm{MSH} 2$ & 5 & $\begin{array}{l}\text { c.873_876delGAC } \\
T \text { [p.L292fs X298] }\end{array}$ & Cd 299 \\
\hline $0531-X$ & MSI-H & $\begin{array}{l}\text { MSH2 pos, MSH6 } \\
\text { neg, MLHI pos. }\end{array}$ & MSH6 & 4 & $\begin{array}{l}\text { c.|42I_I } 422 \text { dupT } \\
\text { G [p.C475fsX480] }\end{array}$ & Cd 480 \\
\hline
\end{tabular}

Cd codon, MS = microsatellite status, pos = staining of $>10 \%$ tumor cells, red = staining of $1-10 \%$ tumor cells, neg $=$ staining of $<1 \%$ of tumor cells, n.d. $=$ not done

\section{Immunohistochemistry}

For immunohistochemistry $3 \mu \mathrm{m}$ thick sections of formalin fixed paraffin embedded tumor tissue were mounted on poly-L-lysine capillary slides and dried overnight at $37^{\circ} \mathrm{C}$. Paraffine sections were dewaxed with xylene, rehydrated in a graded series of alcohol and finally washed in Tris-HCl (pH 7.6) for $10 \mathrm{~min}$. The following steps were performed at room temperature in an automated staining system (TechMate 500, Dako, Glostup, Denmark). To avoid unspecific staining, sections were blocked with buffer 1 (Dako) for 5 min prior to incubation with the primary antibody at the appropriate dilution in blocking buffer (Zytomed, USA) for $30 \mathrm{~min}$ at room temperature. As primary antibodies mouse monoclonal antibodies for MLH1 (BD Biosciences, 1:20), MSH2 (BD Biosciences, 1:20) and MSH6 (BD Biosciences, 1:50) were applied. After several rinses in buffer (Buffer Kit, Dako) the immunoreaction was demonstrated using the APAAP Kit (Dako) according to the specifications of the manufacturer. Fast Red (Dako) was used as alkaline-phosphatase substrate. Finally sections were rinsed in distilled water and counterstained with Mayer's haematoxylin (Dako). Staining was considered only informative when there was normal nuclear staining in adjacent non-neoplastic cells, which served as internal control. Less than $<1 \%$ of stained tumor cells was considered as loss of expression of a MMR protein, whereas $10-100 \%$ of stained tumor cells was considered as normal staining.

\section{Mutation analysis of MLHI, MSH2 and MSH6 genes}

Exons and flanking intronic regions were sequenced by using ABI standard protocols. Primers are available on request. For all systems forward and reverse strands were sequenced. Sequencing was performed corresponding to the immunohistochemical result. If $\mathrm{MSH} 2$ staining was reduced or negative and MSH6 staining negative as well, the MSH2 gene was sequenced at first. Pathogenic relevant mutations were sequenced twice and confirmed in a second blood sample of the patient. Mutations were named according to the nomenclature of den Dunnen and Antonarakis [8].

\section{Results and discussion}

All tumor specimens of the investigated patients showed MSI in at least 2 of five tested loci and therefore were classified as MSI-H. Tumor tissue of all patients was immunohistochemically stained (table 2).

Person 0546-2 showed no MLH1 expression in the tumor compared to normal tissue. The pedigree fulfilled the Amsterdam II criteria. Sequencing analysis revealed the germline mutation c.2198_2199insAACA in exon 19 of MLH1. This frameshift mutation results in a premature stop at codon 746. Sequencing of the whole coding sequence including exon-intron boundaries showed no other abnormalities. Moreover similar mutations near to nucleotide position 2198 of MLH1 have been described earlier as pathogenic.

Patient 0699-3 presented with two metachronous colon cancers at the age of 40 and 53 years (criterion 2 of the old [1] and revised [6] Bethesda guidelines). The tumor tissue of patient 0699-3 showed the MSI-H phenotype. The MLH1 protein was not detectable by immunohistochem- 
istry and a germline mutation c.2076_2077delTG in codon 693 of the MLH1 gene was detected. The resulting protein is predicted to consist of 702 amino acids.

Patient 0545-0 developed left sided colon cancer at the age of 29. The family history fulfilled criterion 2, 3 and 4 of the Bethesda guidelines respectively criterion 1, 2 and 4 of the revised Bethesda criteria. Tumor tissue showed no MSH2 expression and stained negative for MSH6. The latter finding is likely caused by the reported heterodimer formation between MSH2 and MSH6 [9]. Microsatellite analysis of the tumor tissue from this patient revealed a MSI-H status. Sequencing revealed the mutation c.810_811delGT in the MSH2 gene. This deletion of two nucleotides leads to a truncation of the MSH2 protein after 281 amino acids.

In patient $0729-5$ and $0660-6$ we identified the mutation c.763_766delAGTGinsTT [p.F255fsX282] and c.873_876delGACT [p.L292fsX298] respectively in the $\mathrm{MSH} 2$ gene. Tumor tissue of patient 0729-5 staining positive in 1-10\% tumor cells using the MSH2 antibody. The tumor of 0660-6 was immunohistochemically deficient for the MSH2 protein. Microsatellite analysis of tumor tissue of both patients showed MSI-H. The pedigrees of both patients match the Amsterdam I criteria. The immunohistochemical staining of patient 0660-6 is shown in Fig. 1.

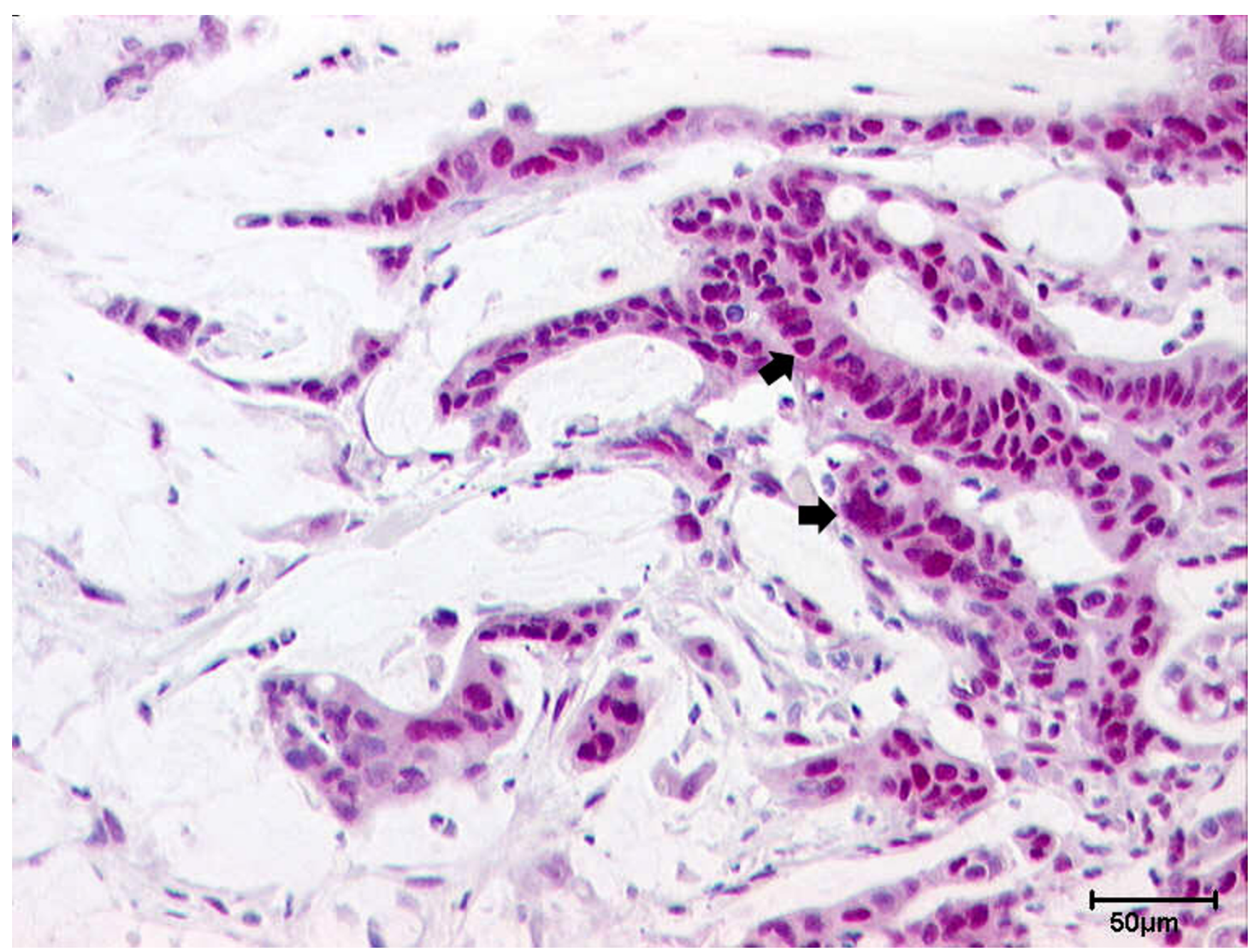

Figure I

MLHI staining Patient 0660-6: Mucinous adenocarcinoma of the colon with a strong nuclear staining (red staining product) of the tumor cells (arrows) for MLHI (I). 


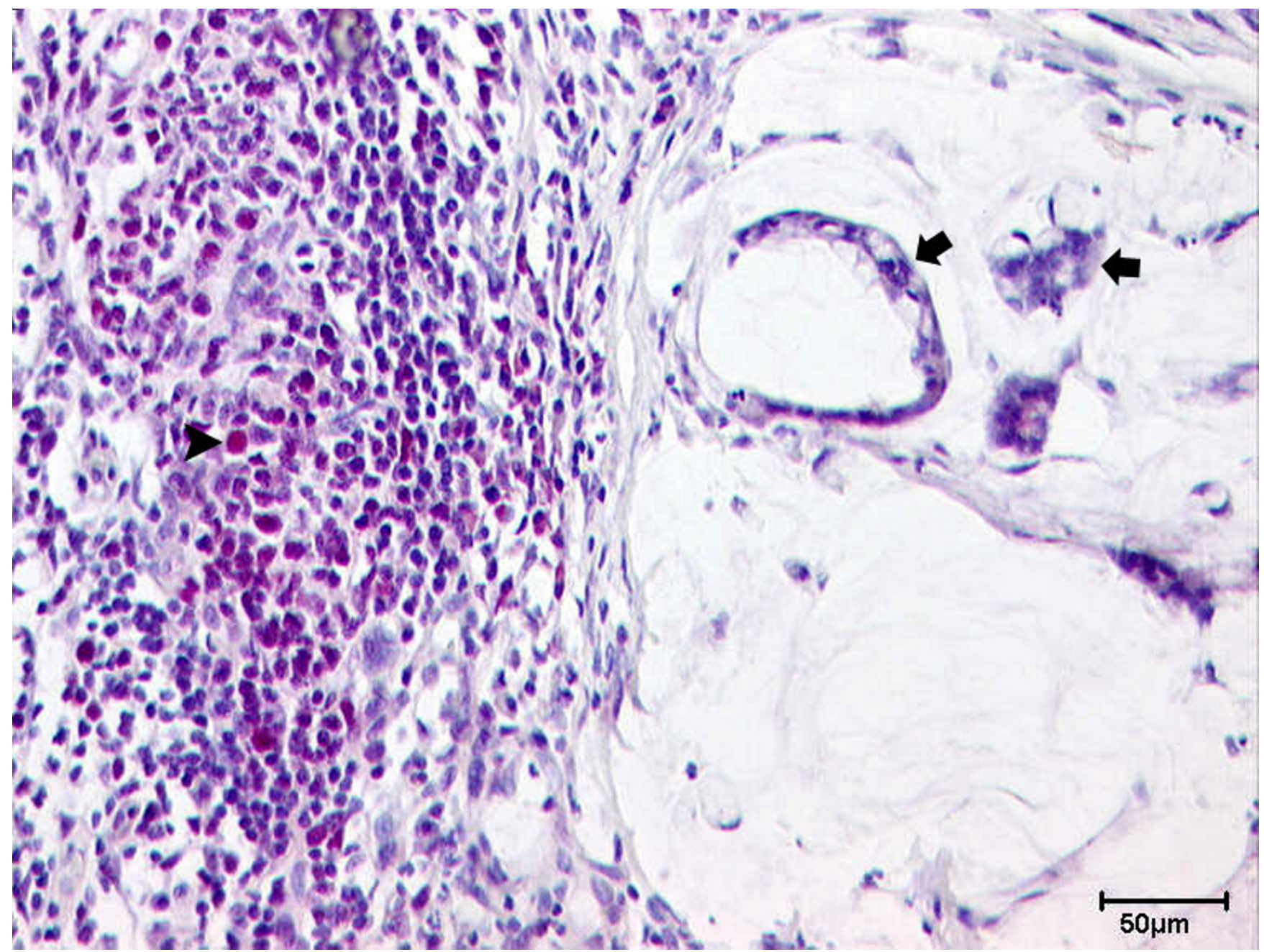

Figure 2

MSH2 staining Patient 0660-6: Mucinous adenocarcinoma of the colon with a negative staining of the tumor cells for MSH2. As an internal positive control, lymphocytes (arrowheads) in an adjacent lymph follicle show a positive nuclear staining for MSH2

Patient 0531-X had tubulovillous adenoma at the age of 39. Colonoscopy was performed annually and the patient developed seven adenomas within a two years follow-up period. The sister presented with an adenoma of unknown histology at the age of 41 . The 40 year old grandmother died of colorectal cancer. So far no female developed endometrial cancer. This pedigree fulfilled criterion 7 of the Bethesda guidelines [1]. Criterion 1 of the revised Bethesda guidelines is met. Tumor tissue of patient 0531-X revealed MSI-H. Firstly, immunohistochemistry of MLH1 and MSH2 was performed only and revealed normal expression of MLH1 and MSH2 protein in the tumor tissue. In addition, immunohistochemistry of MSH6 was done and showed loss of MSH6 protein expression. The frameshift mutation c.1421_1422dupTG
[p.C475fsX480] in the MSH6 gene was detected. The father of the index patient was not affected by HNPCCassociated cancers and is currently aged 65 . Although the published data supports the notion of a later onset of disease in HNPCC families carrying an MSHG mutation, this was not the case in our family. The index patient and her sister started to develop adenomas by the age of 39 and 41 years respectively. Moreover the paternal grandmother died of colorectal cancer at age 40 . These findings are comparable to data for $M L H 1$ and $M S H 2$ mutation positive individuals with HNPCC.

\section{Conclusions}

Our phenotype data imply that HNPCC associated with MSH6 gene mutations may show an age of onset that is 


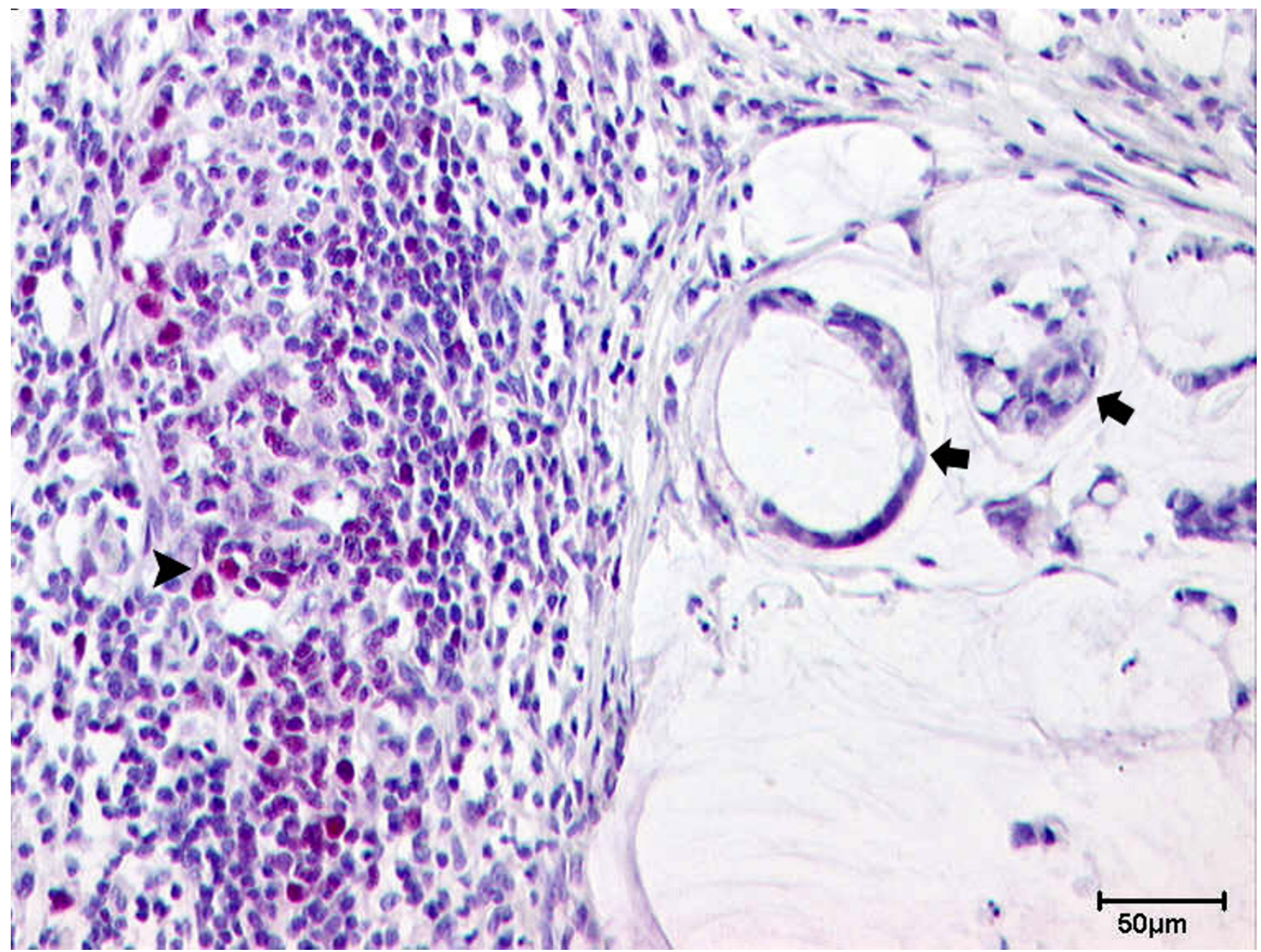

Figure 3

MSH6 staining Patient 0660-6: Mucinous adenocarcinoma of the colon with a negative staining of the tumor cells for MSH6. As an internal positive control, lymphocytes (arrowheads) in an adjacent lymph follicle show a positive nuclear staining for MSH6

comparable to this of patients with $M L H 1$ and $M S H 2$ mutations. Therefore, screening recommendations should not be loosened for families with MSH6 gene mutations.

\section{List of abbreviations}

HNPCC, Hereditary nonpolyposis colorectal cancer; MMR, DNA mismatch-repair; MSI, microsatellite instability; MSI-H, high levels of microsatellite instability; $\mathrm{NIH}$, National Institut of Health; AMS, Amsterdam criteria; B, Bethesda criteria; $\mathrm{B}_{\mathrm{r}}$, revised Bethesda criteria; $\mathrm{CRC}$, colorectal cancer.

\section{Competing interests}

None declared.

\section{Authors contribution}

EK, JV performed the molecular analyses, FEB evaluated the immunohistochemical stainings,

All authors read and approved the final manuscript.

\section{Acknowledgements}

We are grateful to $M$. Scholz for excellent technical support. This work was supported by grants of the German Cancer Aid Foundation (Deutsche Krebshilfe) 70-3033-Schm4, 70-2366-Schm2 to WS

\section{References}

I. Grady WM: Genetic testing for high-risk colon cancer patients. Gastroenterol 2003, I 24: I 574- I594.

2. Liu B, Parsons R, Papadopoulos N, Nicolaides NC, Lynch HT, Watson P, Jass JR, Dunlop M, Wyllie A, Peltomaki P, de la Chapelle A, Hamilton SR, Vogelstein $B$, Kinzler KW: Analysis of mismatch repair 
genes in hereditary non-polyposis colorectal cancer patients. Nat Med 1996, 2:169-174.

3. Kolodner RD, Tytell JD, Schmeits JL, Kane MF, Gupta RD, Weger J, Wahlberg S, Fox EA, Peel D, Ziogas A, Garber JE, Syngal S, AntonCulver H, Li FP: Germ-line msh6 mutations in colorectal cancer families. Cancer Res 1999, 59:5068-5074.

4. Wu Y, Berends MJ, Mensink RG, Kempinga C, Sijmons RH, van Der Zee AG, Hollema H, Kleibeuker JH, Buys CH, Hofstra RM: Association of hereditary nonpolyposis colorectal cancer-related tumors displaying low microsatellite instability with MSH6 germline mutations. Am J Hum Genet 1999, 65: I29I-I298.

5. Wijnen J, de Leeuw W, Vasen $\mathrm{H}$, van der Klift $\mathrm{H}$, Moller $\mathrm{P}$, Stormorken A, Meijers-Heijboer H, Lindhout D, Menko F, Vossen S, Moslein G, Tops C, Brocker-Vriends A, Wu Y, Hofstra R, Sijmons R, Cornelisse C, Morreau H, Fodde R: Familial endometrial cancer in female carriers of MSH6 germline mutations. Nat Genet 1999, 23: I 42-144.

6. Umar A, Boland CR, Terdiman JP, Syngal S, de la Chapelle A, Ruschoff J, Fishel R, Lindor NM, Burgart LJ, Hamelin R, Hamilton SR, Hiatt RA, Jass J, Lindblom A, Lynch HT, Peltomaki P, Ramsey SD, RodriguezBigas MA, Vasen HF, Hawk ET, Barrett JC, Freedman AN, Srivastava S: Revised Bethesda Guidelines for hereditary nonpolyposis colorectal cancer (Lynch syndrome) and microsatellite instability. J Natl Cancer Inst 2004, 96:26I-268.

7. Miller SA, Dykes DD, Polesky HF: A simple salting out procedure for extracting DNA from human nucleated cells. Nucleic Acids Res 1988, 16:1215.

8. den Dunnen JT, Antonarakis E: Nomenclature for the description of human sequence variations. Hum Genet 200I, 109:121-124.

9. Clark AB, Valle F, Drotschmann K, Gary RK, Kunkel TA: Functional interaction of proliferating cell nuclear antigen with MSH2MSH6 and MSH2-MSH3 complexes. J Biol Chem 2000, 275:36498-3650I.

\section{Pre-publication history}

The pre-publication history for this paper can be accessed here:

http://www.biomedcentral.com/1471-2350/5/16/prepub

\section{Publish with Bio Med Central and every scientist can read your work free of charge}

"BioMed Central will be the most significant development for disseminating the results of biomedical research in our lifetime. "

Sir Paul Nurse, Cancer Research UK

Your research papers will be:

- available free of charge to the entire biomedical community

- peer reviewed and published immediately upon acceptance

- cited in PubMed and archived on PubMed Central

- yours - you keep the copyright 